\title{
主鎖型液晶ポリエステルにおける相転移挙動の 分子鎖コンホメーション依存性とせん断応力場での配向挙動
}

\author{
石井 大輔 ${ }^{* 1} \cdot$ 村田 一樹 $* 1, \uparrow \cdot$ 吉谷 博司 ${ }^{* 2} \cdot$ 林 久夫 $^{* 1}$
}

（受付 2009 年 6 月 18 日·審查終了 2009 年 8 月 12 日）

\begin{abstract}
要 旨 本報では, メソゲンとしての 4,4'-ジヒドロキシビフェニルおよび，テレフタル酸ないしイソ フタル酸とアルキル鎖長の異なる八ロゲン化アルコールから主鎖型芳香族液晶ポリエステル $(\mathrm{LCP})$ を合 成し，スペーサーとしてのアルキル鎖長㧍よび芳香環周りの置換様式が相転移挙動に及ぼす影響の検討抢 よび，加熱せん断場における広角 X 線散乱 (WAXS) 測定によるLCP の配向緩和挙動の検討を行った。 LCP の融点や等方化温度にはスペーサーの炭素数による偶奇効果が見られ，テレフタル酸を含む LCP は 奇数の場合に高い転移温度を示したのに対し, イソフタル酸を含む LCP は偶数の場合に高い転移温度を 示した，せん断場に抢けるWAXS 測定では, 高温になるほど LCP の配向緩和が促進される傾向がみら れ，隣接する分子鎖間でのメソゲンのスタッキングが LCP の配向緩和挙動に影響を及ぼすことが示唆 された。
\end{abstract}

\section{1 緒言}

高分子主鎖中にメソゲンとしてはたらく剛直な化学構 造を有し，主鎖の配向と液晶秩序がカップリングする主 鎖型高分子液晶は，主鎖の剛直性に起因する高い弾性と 強度を示す ${ }^{1)}$. 特に，加熱により液晶相を発現するサー モトロピック高分子液晶は, リオトロピック液晶と違い 液晶相発現に溶媒を必要とせず，また溶融状態では分子 構造の異方性の大きさに起因する高い流動性を示すこと から，成形性の良好な環境調和型エンジニアリングプラ スチックとしての利用が期待されている ${ }^{2}$. 実用的に は, より常温に近い温度で液晶相を発現させることがで きれば，成形に要するエネルギーを減少させつつ高い分 子配向度を得ることが可能になる。こうした観点から， 低い液晶相転移温度を有し，な扔かつ広い温度範囲で液 晶相を発現するサーモトロピック高分子液晶の開発が試 みられてきた。

主鎖型高分子液晶の多くは，剛直かつ異方的な構造 (多くは棒状)のメソゲンの長軸方向両末端を屈曲性の高 いスペーサーが連結した主鎖構造を有している3゙．特

*1 龍谷大学理工学部 (寀520-2194 大津市瀬田大江町横谷 15)

*2 積水化学工業(株) (焉618-0021 大阪府三島郡島本町百山 2-1)

†現所属機関・所在地 : 住化バイエルウレタン (株) (㞼6610977 尼崎市久々知 3 丁目 13-26)
に, フェニレン骨格やビフェニレン骨格を有する芳香族 高分子液晶に関して，スペーサーの分子構造が高次構造 および巨視的な物性に及ぼす影響が幅広く研究されてき た4) 6). その一方で，メソゲンの化学構造に関しては多 くの研究では $p$-フェニレン構造に代表される直線的な 構造を有するものであり, 芳香環周りの置換パターンが 高次構造や巨視的物性に及ぼす影響に関する詳細な研究 例は少ない。

高分子液晶の機能を評価する上で，電場や磁場，力場 などの外場が高次構造抢よび巨視的物性に及ぼす影響の 検討は重要である. 外場印加の下での高分子液晶の配向 挙動について, $X$ 線散乱 ${ }^{7) ~ 9)}$ や光散乱 ${ }^{9)}$, 光学顕微鏡 ${ }^{10)}$ によるその場測定が行われてきた。たとえばZhou らは 定常流動状態における主鎖型芳香族液晶ポリエーテルの 分子配向と相転移挙動々の関連について，放射光光源を 用いたその場広角 X 線散乱 (WAXS) 測定による検討 を行っている7)。また，Ania らは磁場印加下での主鎖 型芳香族液晶ポリエステルの配向形成挙動抢よびその温 度依存性について，やはり放射光光源を用いたその場 WAXS 測定による検討を行っている ${ }^{8}$. その一方で, 定常流動状態からの高分子液晶の配向緩和挙動に関する その場 WAXS 測定による検討例は，いまだ報告されて いない.

以上の背景を踏をえて, 本研究では主鎖型芳香族液晶 ポリエステルにおける芳香環周りの置換パターンが液晶 相転移に及ぼす影響を検討するため, 屈曲した分子構造 
石井 · 村田 · 吉谷 $\cdot$ 林

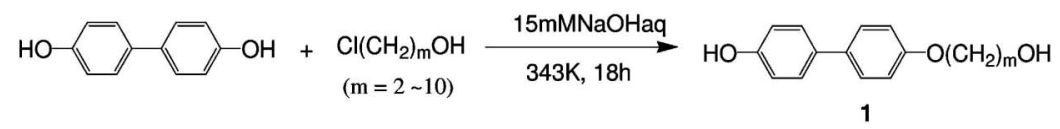

Scheme 1. Synthesis of aromatic dialcohol.

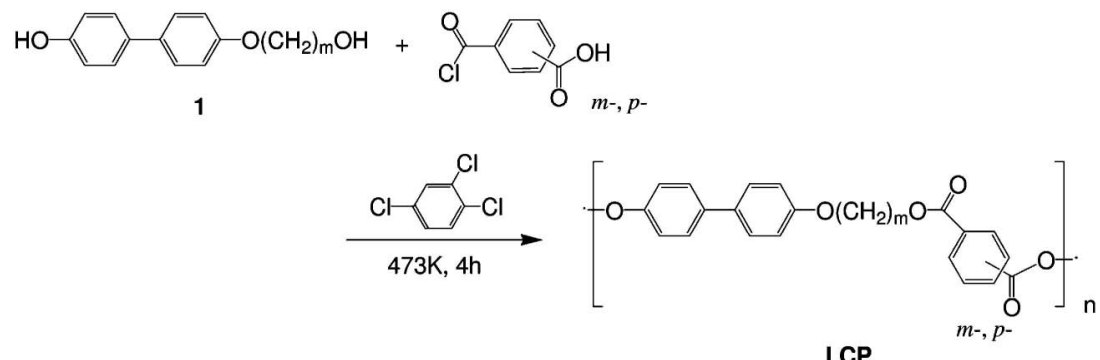

Scheme 2. Synthesis of liquid crystalline polyester (LCP).

を有するイソフタロイル基を主鎖中に導入し，直線的な 分子構造を有するテレフタロイル基を導入した場合との 液晶相転移挙動の違いについて検討を行った。さらに， スペーサーとしてのアルキル連鎖数の偶奇性が液晶相転 移挙動に及ぼす影響も検討した。そして得られた液晶ポ リエステルに加熱下でせん断を加え，その場 WAXS 測 定により配向度および配向緩和挙動の温度依存性につい て検討した。

\section{2 実験の方法}

\section{1 試料の調製}

\subsection{1 芳香族ジアルコールの合成}

4,4'-ジヒドロキシビフェニル $0.3 \mathrm{mmol}$ (和光純薬工業 (株)製)，塩素化脂肪族ジアルコール $\left(\mathrm{Cl}\left(\mathrm{CH}_{2}\right)_{\mathrm{m}} \mathrm{OH}, \mathrm{m}\right.$ $=2 \sim 10$ ，東京化成工業(株)製) $0.1 \mathrm{mmol}$ ，水酸化ナ卜 リウム $0.6 \mathrm{mmol}$ を蒸留水 $400 \mathrm{~mL}$ に加え, $70^{\circ} \mathrm{C}$ にて 18 時間かくはんした。生成した沈殿物を $2 \mathrm{M}$ 水酸化ナトリ ウム水溶液 $150 \mathrm{~mL}$ で洗浄し, 塩酸での中和, 水洗, 減 圧乾燥により芳香族ジアルコール 1 ( $\omega$ - [4- (4-hydroxyphenyl)phenoxy]alkylalcohol) を得た (Scheme 1).

生成物の化学構造の同定は ${ }^{1} \mathrm{H}$ NMR および赤外吸収 (IR) 測定により行った. ${ }^{1} \mathrm{H}$ NMR スペクトルはBruker AVANCE DPX400 分光計を用いて共鳴周波数 $400 \mathrm{MHz}$ にて測定を行った. 試料はすべて DMSO- $d_{6}$ に溶解させた. ${ }^{1} \mathrm{H}$ NMR (DMSO- $\left.d_{6}, \delta\right)$

$\mathrm{m}=7: 1.30-1.45\left(\mathrm{~m}, 8 \mathrm{H},-\mathrm{CH}_{2^{-}} \times 4\right), 1.67-1.72(\mathrm{~m}, 2 \mathrm{H}$, $\left.-\mathrm{O}-\mathrm{CH}_{2}-\mathrm{CH}_{2}^{-}\right), 3.33-3.39\left(\mathrm{~m}, 2 \mathrm{H},-\mathrm{CH}_{2}-\mathrm{OH}\right), 3.97(\mathrm{t}, 2 \mathrm{H}$, Ar-O- $\left.\left.\mathrm{CH}_{2}\right)^{-}\right), 4.34\left(\mathrm{t}, 1 \mathrm{H},-\mathrm{CH}_{2}-\mathrm{OH}\right), 6.79-6.97(\mathrm{~m}, 4 \mathrm{H}$, Ar-H) , 7.38-7.48(m, 4H, Ar-H), 9.44(br. s, 1H, Ar- $\mathrm{OH})$.

$\mathrm{m}=8: 1.24-1.48\left(\mathrm{~m}, 10 \mathrm{H},-\mathrm{CH}_{2^{-}} \times 5\right), 1.75-1.78(\mathrm{~m}, 2 \mathrm{H}$, $\left.-\mathrm{O}-\mathrm{CH}_{2}-\mathrm{CH}_{2}\right), 3.32-3.54\left(\mathrm{~m}, 2 \mathrm{H},-\mathrm{CH}_{2}-\mathrm{OH}\right), 4.00(\mathrm{t}, 2 \mathrm{H}$,
Ar-O- $\left.\mathrm{CH}_{2}{ }^{-}\right), 4.35\left(\mathrm{t}, 1 \mathrm{H},-\mathrm{CH}_{2}-\mathrm{OH}\right), 6.79-6.97(\mathrm{~m}, 4 \mathrm{H}$, Ar-H), 7.39-7.49(m, 4H, Ar-H), 9.50(br. s, $1 \mathrm{H}$, Ar- $\mathrm{OH})$.

$\mathrm{m}=9: 1.21-1.44\left(\mathrm{~m}, 12 \mathrm{H},-\mathrm{CH}_{2^{-}} \times 6\right), 1.67-1.78(\mathrm{~m}, 2 \mathrm{H}$, $\left.-\mathrm{O}-\mathrm{CH}_{2}-\mathrm{CH}_{2}-\right), 3.38-3.54\left(\mathrm{~m}, 2 \mathrm{H},-\mathrm{CH}_{2}-\mathrm{OH}\right), 4.00(\mathrm{t}, 2 \mathrm{H}$, Ar-O- $\left.\mathrm{CH}_{2}{ }^{-}\right), 4.33\left(\mathrm{t}, 1 \mathrm{H},-\mathrm{CH}_{2}-\mathrm{OH}\right), 6.80-7.00(\mathrm{~m}, 4 \mathrm{H}$, Ar-H), 7.39-7.48 (m, 4H, Ar-H), 9.45 (br. s, $1 \mathrm{H}$, Ar- $\mathrm{OH})$.

$\mathrm{m}=10: 1.22-1.48\left(\mathrm{~m}, 14 \mathrm{H},-\mathrm{CH}_{2^{-}} \times 7\right), 1.67-1.80(\mathrm{~m}$, $\left.2 \mathrm{H},-\mathrm{O}-\mathrm{CH}_{2}-\mathrm{CH}_{2}\right), 3.37-3.47\left(\mathrm{~m}, 2 \mathrm{H},-\mathrm{CH}_{2}-\mathrm{OH}\right), 3.97(\mathrm{t}$, $\left.2 \mathrm{H}, \mathrm{Ar}-\mathrm{O}-\mathrm{CH}_{2^{-}}\right), 4.34\left(\mathrm{t}, 1 \mathrm{H},-\mathrm{CH}_{2}-\mathrm{OH}\right), 6.79-6.97(\mathrm{~m}$, $4 \mathrm{H}, \mathrm{Ar}-\mathrm{H}), 7.38-7.48$ (m, 4H, Ar-H) , 9.44(br. s, 1H, Ar$\mathrm{OH})$.

\subsection{2 液晶ポリエステル $(\mathbf{L C P})$ の合成}

$30 \mathrm{~mL}$ の 2 ロフラスコに, 塩化テレフタロイルないし 塩化イソフタロイル (sigma-Aldrich Co. 製) と先に合成 したジアルコール 1 各 $2 \mathrm{mmol}$ を加え，1,2,4-トリクロ ロベンゼン $10 \mathrm{~mL}$ 中で $200^{\circ} \mathrm{C}$ にて 4 時間還流し，メタ ノールで沈殿させ主鎖型芳香族液晶ポリエステル $(\mathrm{LCP})$ を得た (Scheme 2)，LCP の生成は FT/IR スペクトルに おける $1718 \mathrm{~cm}^{-1}$ のエステル $\mathrm{C}=\mathrm{O}$ 伸縮振動および 1230-1290 $\mathrm{cm}^{-1}$ のエステル C-O 伸縮振動に帰属される 吸収ピークから確認した（日本分光 FT/IR-660 使用， $\mathrm{KBr}$ 法により測定)。以下，メチレン連鎖数が $m$ で，テ レフタロイル基ないしイソフタロイル基を含む LCPを, それぞれ tere- $m$ および iso- $m$ と呼称する.

その場 WAXS 測定を行うための LCP 試料は，ホッ トプレスにより $200^{\circ} \mathrm{C}, 10 \mathrm{MPa}$ で加圧した後，氷浴中 で急冷し，直径 $15 \mathrm{~mm}$ のディスク状に削りだしたもの を用いた。

2.2 LCP のキャラクタリゼーション

LCP の相転移温度の決定は示差走査熱量測定 (DSC) 


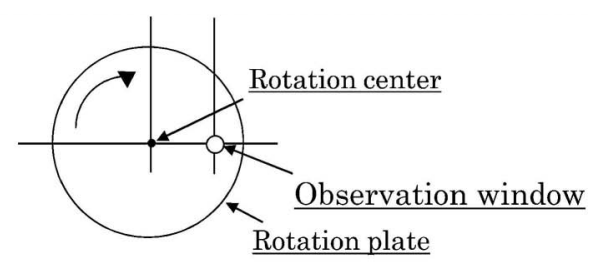

(A) Sample shearing cell.

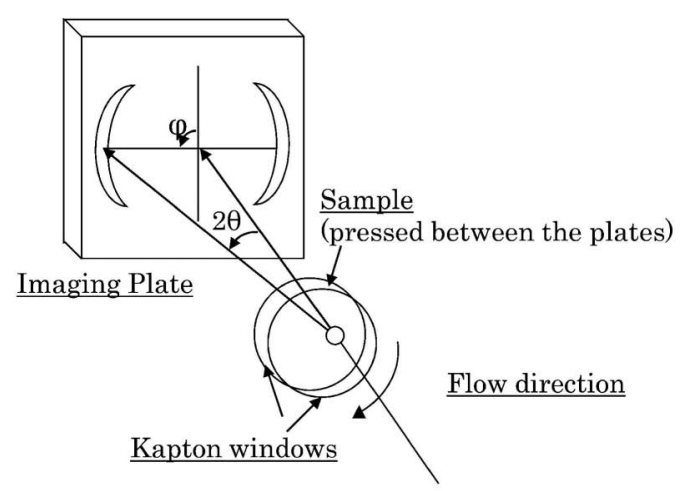

(B) WAXS geometry.

Figure 1. Schemes of (A) sample shearing cell and (B) WAXS geometry.

および加熱下での偏光顕微鏡観察により行った．DSC 測定には Rigaku DSC8230を使用し，参照標準として $\mathrm{Al}_{2} \mathrm{O}_{3}$ を用い, 空気雲囲気下で $10^{\circ} \mathrm{C} / \mathrm{min}$ での昇温およ び降温により 30-300 $\mathrm{C}$ の範囲で測定を行った．偏光顕 微鏡観察には井元製作所 (株)製加熱冷却ステージを装備 した Nikon Optifoto2-POL 偏光顕微鏡を用い，直交二 コル下で $\times 400($ 接眼 $\times 10$, 対物 $\times 40)$ にて観察を行った。

LCP 分子の加熱せん断場における分子配向および 配向緩和挙動の観察は加熱せん断装置を用いたその場 広角 X 線散乱 (WAXS) 測定により行った (Figure 1). 測 定には集光系に多層膜集光ミラーを装備した Rigaku

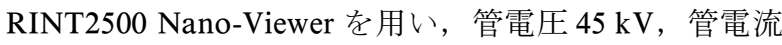
$60 \mathrm{~mA}$ のCu K $\alpha$ 線(波長 $0.1542 \mathrm{~nm}$ ) をスポットサイズ約 $0.5 \mathrm{~mm}$ 程度に集光して照射し, イメージングプレート (IP)を用いて散乱プロファイルの記録を行った。試料一 検出器間距離はシリコン粉末の (111) 面ピーク（面間隔 $0.3135 \mathrm{~nm}$ )により較正した.

その場 WAXS 測定においては試料を 2 枚のカプトン 空板で挟み，X 線源に近い側の空板を回転させ試料に せん断を加えた. そして空板の近傍の金属部分に埋め込 み式のヒーターを設置することで，金属部分から空板へ の伝熱により試料を加熱した。試料厚は $0.8 \mathrm{~mm}$ で, X 線を入射させる部位は空板の赤道軸上の回転中心から $5 \mathrm{~mm}$ 離れた点とした。 せん断速度は $2.6 \mathrm{rad} \cdot \mathrm{s}^{-1}$ に固
定した。

WAXS 測定における LCP の加熱およびせん断印加の 詳細を以下に示す。測定に際しては, 固体状態から液晶 相を発現する温度まで昇温し，所定の温度に到達後 30 分静置した。この時点でせん断印加を開始し，35 分間 せん断を印加した．そしてせん断を停止し 35 分間静置 した。これら一連の過程に抢ける，固体状態，液晶状態 (液晶相発現温度到達から 15 分後), せん断印加 (せん断 開始後 5 分経過時および 25 分経過時)，配向緩和(せん 断停止後 5 分, 50 分, 打よび 95 分ないし 110 分経過 時)の各段階におけるX 線散乱プロファイルを，それぞ れ照射時間 10 分にて記録した。

メソゲンの配向度 $S$ は Hermannの配向関数

$$
S=\frac{1}{2}\left(3\left\langle\cos ^{2} \theta\right\rangle-1\right)
$$

を用いて算出した．ここで $\theta$ はダイレクターと分子長軸 のなす角度，〈〉はアンサンブル平均を表す。配向の 長距離秩序がなければ，メソゲンはあらゆる方位にラン ダムに配向するので $\left\langle\cos ^{2} \theta\right\rangle=1 / 3$ となり， $S=0$ となる. 逆にすべての分子が平行に配列していれば $S=1$ (完全結 晶)である.ネマチック相のように，分子の配向方向に は秩序があるが重心位置がランダムな場合，概ね $S$ は 0.7 程度となる. $\left\langle\cos ^{2} \theta\right\rangle$ は散乱強度の方位角分布より, 次式を用いて算出した.

$$
\begin{aligned}
& \left\langle\cos ^{2} \theta\right\rangle=\frac{\int_{90}^{0} I(\varphi) d(\varphi) \sin (\varphi) \cos ^{2}(\varphi) d \varphi}{\int_{90}^{0} I(\varphi) d(\varphi) \sin (\varphi) d \varphi} \\
& (I \text { : 散乱強度 } \varphi \text { : 方位角 })
\end{aligned}
$$

実際の算出に当たっては, 散乱強度の方位角プロファ イルの極大位置を $\varphi=0^{\circ} に$ 移動させて計算した.

\section{3 結果と考察}

\section{1 液晶相転移の主鎖構造依存性}

合成されたポリエステルについて DSC 測定を行い, 観測される吸熱ピークの数から液晶性の有無を定性的に 判定することを試みた. tere-2, 4 と iso-3 では単一の融 解ピークしか観測されず，液晶相の発現は確認されな かった. 一方, tere-3, tere-5〜10 と iso-2, iso-4〜10で は昇温時に複数の吸熱ピークが観測されたことから，こ れらのポリエステルが液晶性を有することが確認され た。これらの結果より，液晶相を発現させるには，メソ ゲンであるビフェニル基と主鎖骨格全体の配向のカップ リングを小さくするために，スペーサーとしてある程度 以上の長さのメチレン連鎖が必要であるということが わかる。 

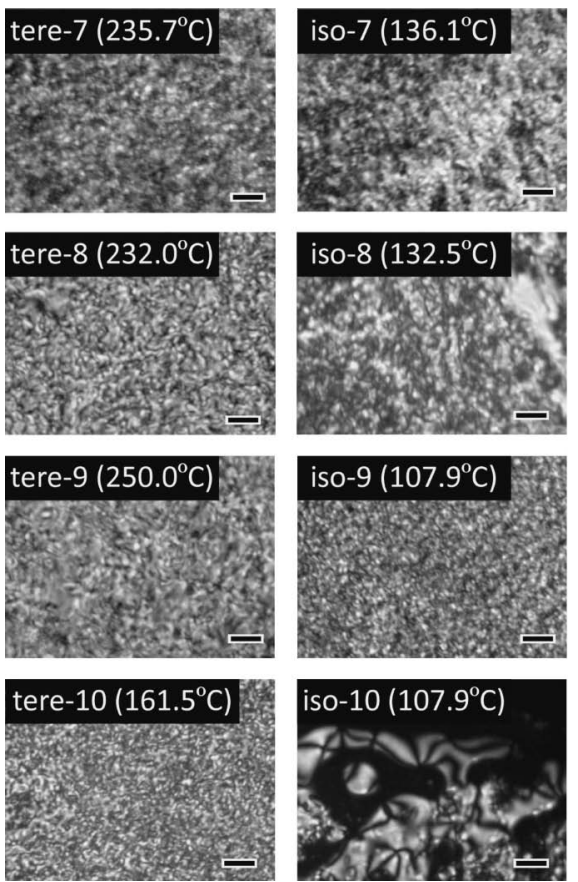

Figure 2. Cross-polarized optical micrographs of LCPs. Bars: $10 \mu \mathrm{m}$.

Figure 2 は液晶状態にある各 LCP の偏光顕微鏡写真 であるすべての LCPにおいて，10 $10 \mathrm{~m}$ 以下のスケー ルのシュリーレン組織が確認された。この大きさは低分 子液晶で見られるものに比べると非常に小さい。これ は，メソゲンが高分子主鎖中で共有結合による運動の 制約を受けているため，長距離にわたる秩序構造の形成 が困難であるためと考えられる。しかしながら，iso-10 に拉いてのみ，他の LCP に比べてより大きなサイズの シュリーレン組織が形成された。これはイソフタロイル 基を有することにより主鎖の屈曲性が増大していること と，長いメチレンスペーサーを有することによりメソゲ ンを含む主鎖の運動性が増大することで，メソゲンの配 列が容易になったためと考えられる.

Figure 3 は偏光顕微鏡観察により求められた tere-3, 5 〜10 と iso-2, 4〜10 の融点抢よび等方化温度をメチレン 連鎖数に対してプロットしたものである. tere 体および iso 体いずれにおいても，等方化温度にはメチレン連鎖 数に応じて交互に大小が生じる偶奇性がみられた。この ような偶奇性は二量体液晶にしばしばみられるもの で11), メチレン連鎖数が偶数と奇数の場合でメソゲンが 主鎖の長軸に対し平行もしくは傾斜して配置することに 起因する. Tere 体では奇数の場合，iso 体では偶数の場 合に高い等方化温度を示すのは，これらの組合せにおい てメソゲンが分子軸に対して平行に配置し，分子の直線 性がより高くなるためと考えられる．Figure 4 に示すよ うに，隣接メチレン基間のコンホメーションがすべてト

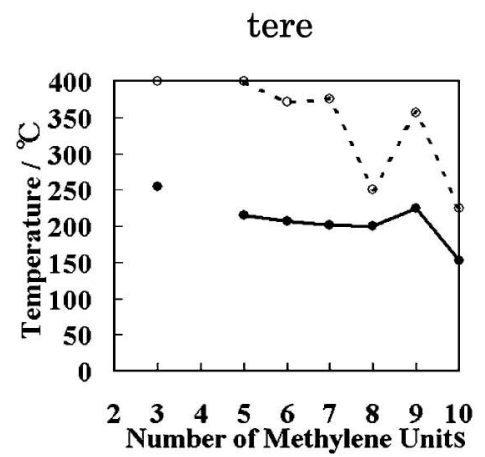

iso

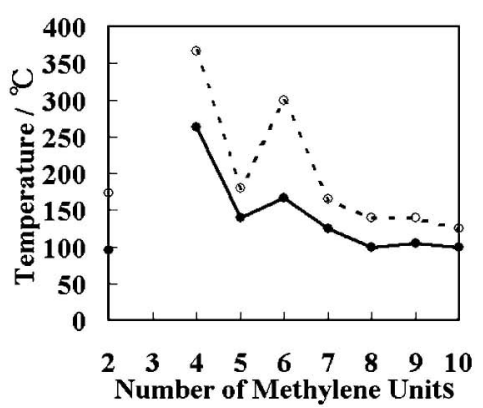

Figure 3. Transition temperatures of LCPs as a function of the number of methylene units in the spacer. $\bullet$; melting temperature, $\bigcirc$; clearing temperature. Temperatures were visually determined from polarized optical microscopy.
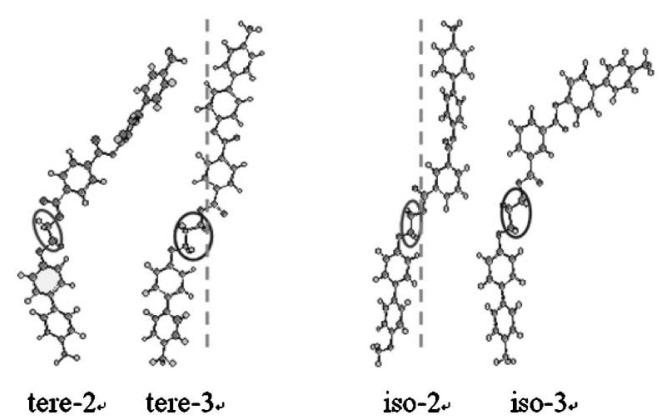

Figure 4. Comparison of the molecular conformations of LCPs. From left to right: tere-2, tere-3, iso-2, and iso-3.

ランス構造の場合を考えると，メソゲン長軸方向と分子 鎖の向きのズレは tere 体では奇数の場合に比べて偶数 の場合の方が大きく，iso 体では逆の傾向を示す．こう したメチレン連鎖数と分子形態の関係が， tere 体と iso 体とで転移温度の偶奇性が逆に表れたことに反映されて いる. その一方, tere 体, iso 体ともに, メチレン連鎖 数が増加するに伴って融点の低下が見られた。これはス ペーサーとしてのメチレン連鎖が長くなったことによる メソゲンの運動性の増大を反映している。ささらに, tere 体に比べて iso 体では，融点および等方化温度が全体的 に低下し，かつ液晶温度範囲が小さい傾向がみられた。 このことは芳香環周りの結合位置による分子形態の違い 
が相転移挙動により大きな影響を及ぼし，より直線性の 高い構造を有する tere 体に抢いて広い温度範囲にわた り液晶秩序が形成されることを示している。

以上のような一連の化合物の液晶相転移挙動に基づ き，実際にこれらの液晶場を利用しエンジニアリングプ ラスチックとのブレンドで材料を成形することを考えて みる. LCP が液晶状態でかつブレンド材料も融点以上 であれば効率的に配向を制御することができる。その際 の配向制御は等方化点に近いほど分子鎖間相互作用が小 さいために効率が良いはずである。一例として代表的な エンジニアリングプラスチックであり $225^{\circ} \mathrm{C}$ 付近で融点 を示すポリ (ブチレンテレフタレート) (PBT) と本研究で 用いた LCP のブレンドを考えると，iso体はその等方 化温度が PBTの融点に対して低すぎ，一方 tere 体の多 くは PBT の融点に対して相当高い等方化温度を有する ため，PBTの配向制御には利用しにくい。しかしなが ら, PBT の融点と同じ $225^{\circ} \mathrm{C}$ 付近で液晶相を発現し， かつ低い等方化温度を有する tere-8 は，PBT に混合す ることで押出成形時に配向形成による補強効果を発現す ることが期待される。こうした観点から， tere-8の加熱 せん断場における配向抢よび緩和挙動に関して，その場 WAXS 測定による検討を行うこととした.

\section{2 加熱せん断場における LCP の配向および緩和挙 動}

\subsection{1 温度およびせん断場の配向面間隔への影響}

Figure 5(A) に，固体状態， $210^{\circ} \mathrm{C}$ に打液晶状態， せん断印加下，そしてせん断停止から所定の時間経過し た状態での tere-8 LCP の二次元 WAXS パターンを示 す。液晶状態における散乱パターンは固体状態に比べて 若干異方性の大きいものとなった。これは融解によって LCP が重力の影響を受け鉛直方向への流動配向が生じ たことを示す。さらにせん断印加によって散乱パターン は赤道上に偏った形となった。これは加熱によって形成 されるポリドメイン状の液晶組織が，せん断場に抢ける 個々のドメインのダイレクターの整列によりモノドメイ ン構造に変化したことを示している. 同様の散乱パター ンの変化は側鎖型液晶エラストマーの引張においても観 察されている ${ }^{12)}$ 。 せん断によって異方的になった散乱パ ターンは，せん断停止後もほとんど変化しなかった。こ れは $210^{\circ} \mathrm{C}$ という温度が tere- 8 の融点に近いために, LCP の分子運動性が固体状態に近い低いものにとどま り，誘起された配向が緩和せずに保持されたためと考え られる。

一方，Figure 6(A) に示すように $230^{\circ} \mathrm{C}$ まで昇温した 場合，せん断を印加しない状態においても散乱パターン の異方性がより強く表れた。これは等方化温度により近 い温度まで昇温したことによる LCP の流動性の増大を 反映している.さらにせん断を加えることで赤道付近に
(A)

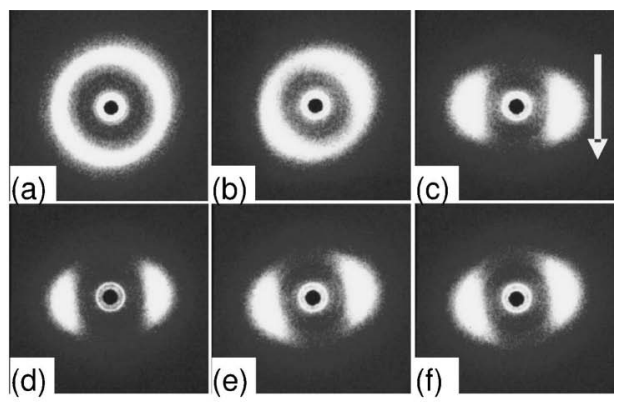

(B)

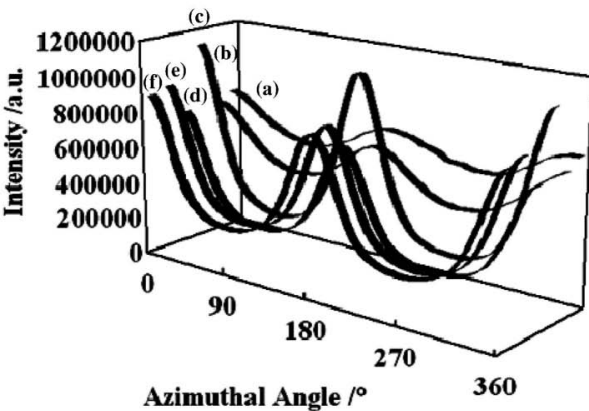

Figure 5. (A) In situ 2-dimensional WAXS patterns of tere-8 LCP observed (a) in solid state, (b) on heating at $210^{\circ} \mathrm{C}$, (c) under shear, and (d) $5 \mathrm{~min}$, (e) $50 \mathrm{~min}$, (f) $95 \mathrm{~min}$ after cessation of shear. Arrow in (c) indicates the shear direction. (B) Azimuthal distibution of scattering intensity at each stage.
(A)

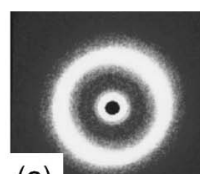

(a)

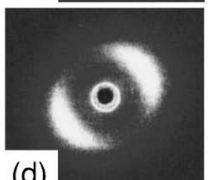

(d)

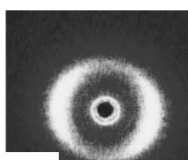

(b)

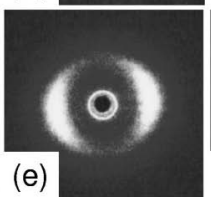

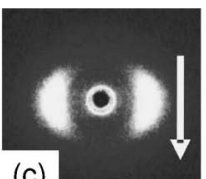

(c)

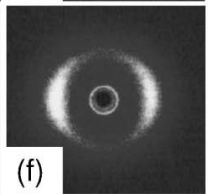

(B)

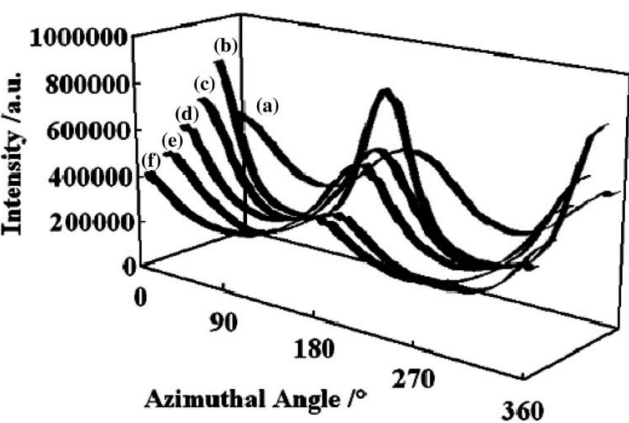

Figure 6. (A) In situ 2-dimensional WAXS patterns of tere-8 LCP observed (a) in solid state, (b) on heating at $230^{\circ} \mathrm{C}$, (c) under shear, and (d) $5 \mathrm{~min}$, (e) $50 \mathrm{~min}$, (f) $110 \mathrm{~min}$ after cessation of shear. Arrow in (c) indicates the shear direction. (B) Azimuthal distribution of scattering intensity at each stage. 
(A)

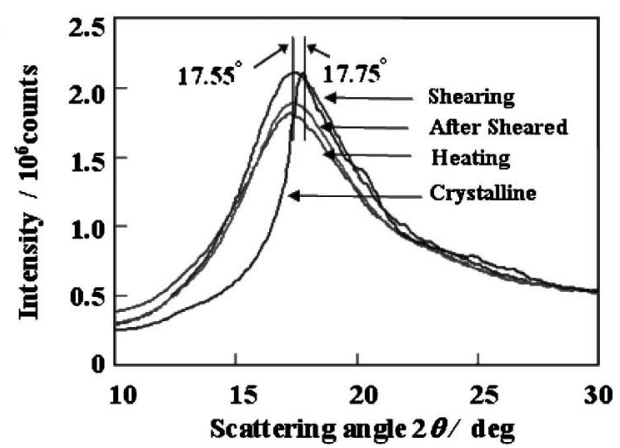

(B)

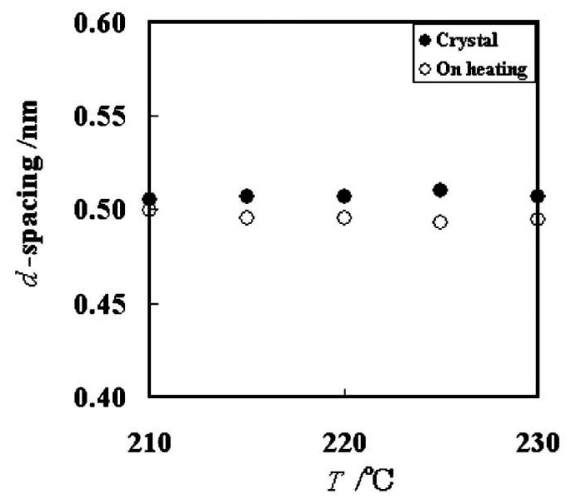

Figure 7. (A) Circularly averaged WAXS pattern of tere-8 LCP at crystalline state, on heating, shearing, and after shear at $210^{\circ} \mathrm{C}$. (B) Temperature dependence of d-spacing estimated from circularly averaged WAXS profile.

偏った散乱パターンとなり，せん断停止後は方位角方向 に傾斜した散乱パターンを経て, 徐々にせん断印加前の 円周状に近い散乱パターンに変化した．これらの変化は せん断方向に配列した状態からメソゲンの配向が緩和し てポリドメイン配向になっていく過程を反映している. $210^{\circ} \mathrm{C}$ で観察されなかったこれら一連の挙動は, $230^{\circ} \mathrm{C}$ に扔いて LCP の分子運動性が増大したことで，せん断 によって蓄積した応力が配向緩和により散逸したことを 示している. 一連の過程に抢ける方位角方向の散乱強度 分布の変化を Figure 5(B) 拉よび Figure 6(B) に示す. $210^{\circ} \mathrm{C}$ に扔いてはせん断配向による異方的な散乱がせん 断停止後も減衰しなかったのに対し， $230^{\circ} \mathrm{C} て ゙ は$ 時間経 過とともに減衰した。

Figure 7 (A) に $210^{\circ} \mathrm{C}$ に抢ける 2 次元 WAXS パターン の円環平均を取ることにより得られた散乱強度の $2 \theta$ プ ロファイルを示す．固体状態では $2 \theta=17.75^{\circ}$ に, 液晶状 態とせん断下では $2 \theta=17.55^{\circ}$ に回折ピークが観測され た.これらのピークは Bragg の式よりそれぞれ $d=4.96$ 凡抢よび $5.00 \AA$ に対応する。この面間隔值はポリマー の構造より, 固体状態㧍よび液晶状態に抢けるメソゲン 間の平均隣接距離と見なすことができる. 固体状態に比
べて液晶状態でごくわずかながら面間隔值が増大したの は, 融点以上でメソゲンの熱運動により自由体積が増大 したことを反映している。また，液晶状態とせん断下で 面間隔值に違いが見られなかったことから，せん断はメ ソゲン間の隣接距離に影響を及ぼさず, 配向にのみ影響 を及ぼすことがわかる．Figure 7(B)に示すように，2 2 方向でのピーク位置における散乱強度を温度ごとにプ ロットしたところ, どの温度に扔いてもピーク強度は一 様であった，すなわち液晶状態における LCP の面間隔 は, 温度に依存しないことがわかった。このことは, 液 晶状態における LCP の秩序構造が, 主に分子鎖長軸方 向の運動によって形成されることを示唆している.

\subsection{2 分子配向のせん断場における経時変化および 温度依存性}

WAXS プロファイルに打ける散乱強度の方位角依存 性からメソゲンの配向度を算出した。せん断停止後, メ ソゲンの配向には緩和が見られ, 配向度は滑らかな曲線

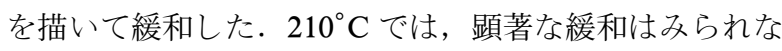
かったが， $215^{\circ} \mathrm{C}$ 以降では 0.1 以下まで緩和した。この 值は, せん断をかける前の加熱時における配向度に近い 值である。緩和過程に抢ける配向度は加熱温度に依存 し, 高温ほど, せん断停止後の配向度が低くなった. 加 熱温度 $210^{\circ} \mathrm{C}$ で配向緩和が見られなかったのは, 用い た LCP である tere-8 のガラス転移温度のごく近傍であ り，LCP はなおガラス状態に近い低い流動性しか有し ていないために, せん断により誘起された配向がせん断 停止後も残存したためと考元られる。

ここで, せん断亭止後の配向度が時間に対して指数関 数的に減少していると仮定し, 配向度 $S$ のせん断停止 後経過時間 $t$ に対する片対数プロットの傾きより緩和時 間を算出した (Figure 8 (B)). 緩和時間は, 低温からそ れぞれ 469,184, 74, 68, 124 分となり, 試料温度の増大 に伴い小さな値となった．このことは LCP の熱運動の 活性化に伴いメソゲンの回転運動の障壁が小さくなるこ とを意味している。しかしながら， $230^{\circ} \mathrm{C} て ゙ は$ 緩和時間 が 124 分となり， $225^{\circ} \mathrm{C}$ に抢ける緩和時間よりも大きな 值となった。これは試料温度が等方化温度 $\left(250^{\circ} \mathrm{C}\right)$ に近 くなることで, ポリマーの粘性が低下し重力方向への流 動配向が生じ, せん断によって誘起された配向の緩和が 阻害されたためと考えられる。

Figure 8 $(\mathrm{C})$ に緩和時間の温度依存性に関する Arrhenius プロットを示す. $210^{\circ} \mathrm{C}$ から $225^{\circ} \mathrm{C}$ までの範囲 で活性化エネルギーを算出したところ, 活性化エネル ギーは $265 \mathrm{~kJ} / \mathrm{mol}$ となった。この値は James らが主鎖 型スメクチック液晶ポリエステルについて定常流粘度測 定により算出した流動の活性化エネルギーである 275 $\mathrm{kJ} / \mathrm{mol}$ とよく一致している ${ }^{13)}$. 彼らはこの活性化エネ ルギーの值に関して, せん断により分子鎖の伸長方向に 
(A)

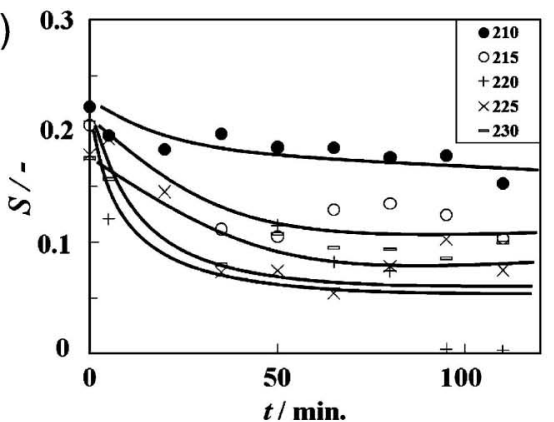

(B)

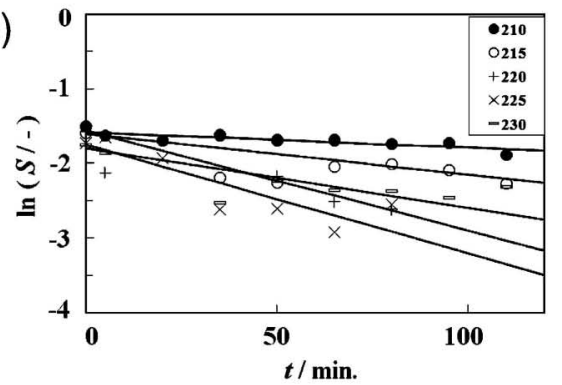

(C)

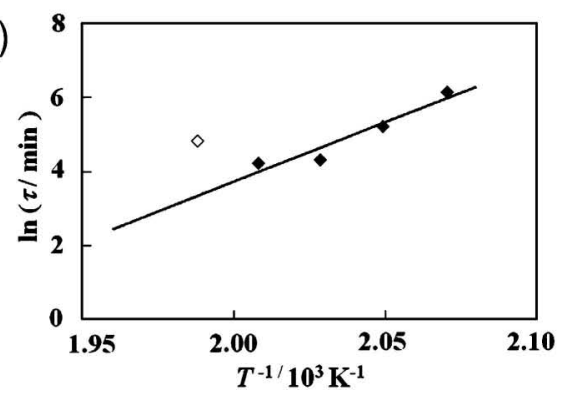

Figure 8. (A, B) Linear (A) and semilogarithmic (B) plot of orientational order parameter, $S$, of tere- $8 \mathrm{LCP}$ as a function of time elapsed after cessation of shear at different temperatures $\left(\right.$ in $\left.{ }^{\circ} \mathrm{C}\right)$. (C) Arrhenius plot of orientational relaxation time, $\tau$, between 210 and $225^{\circ} \mathrm{C}$. The data for $230^{\circ} \mathrm{C}$ (empty symbol) was omitted from consideration due to possible gravitational flow.

おける並進運動が起こり，その結果隣接メソゲン間のス タッキングにずれが生じる Noel らのモデル14)を引用し

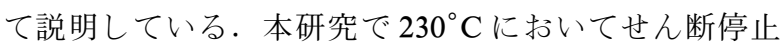
直後に観測された方位角方向における散乱パターンの傾 斜は, これら既往の研究で示唆された, 隣接メソゲン間 の長軸方向での位置のずれによる秩序構造の変化を直接 的に示すものである.

本報では専ら広角域での散乱パターンから LCP の配 向挙動について議論したが, 長距離秩序の影響がより強 く表れる小角域での散乱パターンについても検討するこ とで, せん断場における LCP の配向挙動のより詳細な 情報が得られると期待される。

\section{文献}

1) A. Blumstein, C. H. Lin, A. K. Mithal, and A. Tayebi, $J$. Appl. Polym. Sci., 41, 995 (1990).

2) W.-J. Zhou, J. A. Kornfield, and W. R. Burghardt, Macromolecules, 34, 3654 (2001).

3) R. W. Lenz, Polym. J., 17, 105 (1985).

4) J. Watanabe and M. Hayashi, Macromolecules, 21, 278 (1988).

5) J. Watanabe and M. Hayashi, Macromolecules, 22, 4083 (1989).

6) J. Watanabe and S. Kinoshita, J. Phys II France, 2, c1237 (1992).

7) W.-J. Zhou, J. A. Kornfield, V. M. Ugaz, W. R. Burghardt, D. R. Link, and N. A. Clark, Macromolecules, 32, 5581 (1999).

8) F. Ania, A. Flores, H. R. Kricheldorf, and F. J. BaltaCalleja, Polymer, 44, 5909 (2003).

9) M. Tokita, K.-W. Kim, S. Kang, and J. Watanabe, Macromolecules, 39, 2021 (2006).

10) P. T. Mather, A. Romo-Uribe, C. D. Han, and S. S. Kim. Macromolecules, 30, 7977 (1997).

11) H. Furuya, K. Asahi, and A. Abe, Polym. J., 18, 779 (1986).

12) S. M. Clarke, E. M. Terentjev, I. Kundler, and H. Finkelmann, Macromolecules, 31, 4862 (1998).

13) S. G. James, P. Navard, and C. Noel, Rheol. Acta, 29, 366 (2008).

14) C. Noel, C. Friedrich, L. Bosio, and C. Strazielle, Polymer, 25, 1281 (1984). 


$$
\text { 石井 · 村田 · 吉谷 · 林 }
$$

Phase Transition, Shear-Induced Orientation and Relaxation Behavior of Main-Chain Liquid Crystalline Polyester: Effect of Molecular Conformation

Daisuke Ishi ${ }^{* 1}$, Kazuki Murata ${ }^{* 1, \dagger}$, Hiroshi Yoshitani ${ }^{* 2}$, and Hisao HaYashi*1

${ }^{* 1}$ Department of Materials Chemistry, Faculty of Science and Engineering, Ryukoku University (1-5 Yokotani, Seta Oe-cho, Otsu-shi 5202194, Japan)

${ }^{* 2}$ Sekisui Chemical Co., Ltd. (2-1 Hyakuyama, Shimamoto-cho, Mishima-gun, Osaka 618-0021, Japan)

Phase transition, orientation under shear and relaxation behavior of thermotropic main-chain liquid crystalline polyesters (LCP) synthesized from $\omega$-[4-(4-hydroxyphenyl) phenoxy]alkyl alcohols with different alkyl unit length and terephthalic or isophthalic acid were investigated. Formation of liquid crystalline phase at the elevated temperatures was observed for the polyesters containing methylene sequences with more than 4 methylene units. Odd-even effect of the number of methylene units on the phase transition temperatures of LCP was observed. Furthermore, terephthalic and isophtalic LCPs showed different phase transition behaviors. These results show that the molecular conformation, determined by the number of methylene units and substitution pattern in aromatic rings, affects the phase transition of LCPs. Molecular orientation under shear and the relaxation behavior was investigated by in situ WAXS experiments.

KEY WORDS Liquid Crystalline Polyester / Thermotropic Phase Transition / Molecular Conformation / WAXS /

Shear-Induced Orientation / Relaxation /

(Received June 18, 2009: Accepted August 12, 2009)

[Kobunshi Ronbunshu, 66, 619-626 (2009)] (C)2009, The Society of Polymer Science, Japan

${ }^{\dagger}$ Present Address: Sumika Bayer Urethane Co. Ltd. (3-13-26 Kukuchi, Amagasaki-shi 661-0977, Japan) 